\title{
Practical ministry and finances: A case study from InnerCHANGE South Africa
}

\begin{tabular}{|c|c|}
\hline $\begin{array}{l}\text { Author: } \\
\text { Kgotso K.T.L. K }\end{array}$ & abongo $^{1}$ (1) \\
\hline $\begin{array}{l}\text { Affiliation: } \\
{ }^{1} \text { Department } \\
\text { Studies, Facult } \\
\text { and Religion, } \\
\text { of Pretoria, Ts } \\
\text { South Africa }\end{array}$ & $\begin{array}{l}\text { f Religion } \\
\text { y of Theology } \\
\text { University } \\
\text { iwane, }\end{array}$ \\
\hline $\begin{array}{l}\text { Research Proj } \\
\text { Project Leade } \\
\text { Project Numb }\end{array}$ & $\begin{array}{l}\text { ct Registration: } \\
\text { : A. van Niekerk } \\
\text { er: } 02461412\end{array}$ \\
\hline $\begin{array}{l}\text { Description: } \\
\text { This research } \\
\text { research proje } \\
\text { The church an } \\
\text { communities', } \\
\text { by Dr Attie var } \\
\text { Department o } \\
\text { Religion and } \\
\text { Faculty of The } \\
\text { Religion, Univ } \\
\text { Pretoria. }\end{array}$ & $\begin{array}{l}\text { s part of the } \\
\text { ct, 'Ecodomy: } \\
\text { d sustainable } \\
\text { directed } \\
\text { Niekerk, } \\
\text { Science of } \\
\text { lissiology, } \\
\text { logy and } \\
\text { rsity of }\end{array}$ \\
\hline $\begin{array}{l}\text { Correspondin } \\
\text { Kgotso K.T.L. K } \\
\text { kablut@yahoc }\end{array}$ & $\begin{array}{l}\text { author: } \\
\text { abongo, } \\
\text { fr }\end{array}$ \\
\hline $\begin{array}{l}\text { Dates: } \\
\text { Received: } 03 \mathrm{~J} \\
\text { Accepted: } 21 \\
\text { Published: } 25\end{array}$ & $\begin{array}{l}\text { uly } 2020 \\
\text { an. } 2021 \\
\text { Feb. } 2021\end{array}$ \\
\hline $\begin{array}{l}\text { How to cite th } \\
\text { Kabongo, K.K. } \\
\text { 'Practical mini } \\
\text { finances: A ca } \\
\text { InnerCHANGE } \\
\text { HTS Teologies } \\
\text { Theological St } \\
77(4) \text {, a6230. } \\
\text { org/10.4102/ }\end{array}$ & $\begin{array}{l}\text { is article: } \\
\text {.L., 2021, } \\
\text { stry and } \\
\text { e study from } \\
\text { South Africa', } \\
\text { Studies/ } \\
\text { ıdies } \\
\text { ittps://doi. } \\
\text { ts.v77i4.6230 }\end{array}$ \\
\hline $\begin{array}{l}\text { Copyright: } \\
\text { (C) 2021. The A } \\
\text { Licensee: AOS } \\
\text { is licensed unc } \\
\text { Creative Comr } \\
\text { Attribution Lic }\end{array}$ & $\begin{array}{l}\text { uthors. } \\
\text { S. This work } \\
\text { ler the } \\
\text { nons } \\
\text { ense. }\end{array}$ \\
\hline Read online: & \\
\hline 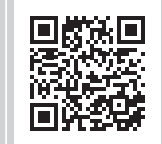 & $\begin{array}{l}\text { Scan this QR } \\
\text { code with your } \\
\text { smart phone or } \\
\text { mobile device } \\
\text { to read online. }\end{array}$ \\
\hline
\end{tabular}

The church is called to be a tangible messenger of hope in society. Communities of poverty, especially, need a church that carries its mandate both through proclamation and through deed. This research is a case study of a team located in South Africa that is part of an international missional order called InnerCHANGE. The latter focuses on discipleship and the nurturing of local leaders who are community builders in areas of poverty. This focus is expressed through practical ministry initiatives. The latter necessitates finances through the team does not always have. A desire to overcome its financial challenges led it to decide to get some training in financial literacy, so that it can improve its fundraising efforts. This training was provided by a finance broker. The latter started his teaching with personal finances before going into organisational finances. He believed that good personal financial stewardship leads to good corporate financial stewardship. The outcome of this training led ICSA staff and the board of directors to diversify their fundraising efforts and to set the target of saving 15\% of its income. The work is still in progress for reaching this target. However, for 2 years in a row, ICSA has been making some good progress in increasing its income and savings. This article concludes by advising the body of Christ serving from below to pursue training in financial management so that it can strengthen its checks and balance system which could lead to sustainability.

Contribution: This article contributes to the on-going discussions about financially sustainable models of the church from below in Africa so that the church can remain an important role player in serving local communities practically. It uses InnerCHANGE South Africa as a case study of such efforts.

Keywords: finances; fundraising; generosity; savings; sustainability.

\section{Introduction}

The church has the task and calling to be a tangible messenger of hope, love and care in society. Communities of poverty, especially, need a church that carries its mandate both through proclamation and through deed. InnerCHANGE is an international missional order that believes in this dual mandate of the church. It serves in the contexts of poverty through service projects. It has 16 teams around the world. It also uses practical service initiatives as a platform to do discipleship and catalyse the raising of local leaders who are community builders. The running of service projects necessitates finances that teams do not always have. This study is a quest for financial sustainability, so that InnerCHANGE can maintain its service projects and effectively respond to other emergencies that may necessitate finances.

This article is a case study investigating how the team of InnerCHANGE South Africa (ICSA thereafter) can sustain its 'socio-caritative actions' (Latvus 2010:1). It is attempting to align itself with the existing positive legacy of the church in serving the vulnerable practically. The sustenance of these services requires finances that ICSA needs to raise and manage well. This is a challenge that led it to practically grapple, through qualitative research, with how the church serving in communities where skills and resources in financial management are scarce can equip itself for sustainability sake. This journey is guided by this question: how can we improve our financial literacy and stewardship, so that we can sustain our ministry initiatives? In the quest to respond to this question, ICSA approached a finance broker, David Finney, for the training of its staff and volunteers. In that training, they were advised that the best way to start responding to their question was to seek personal finance literacy. According to the finance broker, the latter usually leads to good organisational financial management. 


\section{Personal finances}

Finney (2019) taught the team some important principles. None of the trainees had learnt any of those principles from their homes, schools or local congregations. These three institutions are supposed to holistically prepare the members, including financial literacy. Unfortunately, none of the trainees had had such a privilege. This may be a reality of the entire South African society. It is said that many South Africans struggle to manage their finances well and are unable 'to save' any money (Smith 2019:1).

The team learnt that good financial management follows some principles and laws that can be learnt and followed. These principles are inspired by George Clason's (2018) opinion that 'money is plentiful for those who understand the simple laws which govern its acquisition'. These laws are purchasing things in cash, generosity, prioritising selfpayment, avoidance of emotional purchases and an awareness that there is nothing free of charge in life.

\section{Purchasing things in cash}

Nowadays, consumers are encouraged to take products now and pay later. They are also encouraged to borrow or to charge things on an account. In the local community ICSA serves in, loan shacks are heavily relied upon by ordinary people. Through them, people can quickly get what they want. The result is that many people are indebted in necessary and unnecessary things.

Many ICSA trainees in the room resonated with this reality. Some people said that there is a general belief in the community that no adult can survive without owing money to someone. The team learned that wise consumers should aim to buy whatever they need with the money they have. If the purchasing amount is exorbitant, a wise consumer should first save money towards it and still buy in cash. The reality is that anything bought on credit or put on an account costs more than its cash price. Such a behaviour frees up a consumer from the bondage of debt. Lenders are well known for harassing borrowers to pay back what they owe. A wise consumer culture would free up a Christian from serving two masters: money lenders and God (Mt 6:24).

Generally, there are four principles of staying debt free, which have led many people to prosperity, success and happiness. These principles are captured in the following words: 'Spend less than you get' (Franklin 2007). Harris and Coonradt (1999) wrote the book 'The four laws of debt-free prosperity', a tool that has helped numerous people take control of their finances and live a well-balanced life. These principles are:

- Tracking. This is about keeping track of all expenses made daily. Odiorne (1990) stresses ‘If you can't measure it, you can't manage it'. This is a discipline and practice that could enable someone to identify the leaks or flow of where the money is going. Many people under-estimate how much they spend. What gets measured, improves. When someone knows where and on what money is spent on, chances of stewardship improve.
- Targeting. It is important to have personal goals and targets. Without them, people tend to concentrate on the here and now activities and become enslaved by them. Meyer (2003) states that 'personal goal setting is the strongest force in the world'. A goal or target that is not intentionally focused on is merely a wish. It needs to be SMART:

- Specific to someone's circumstances and relevant.

- Measurable in having a clear expected outcome.

- Achievable in being realistic.

- Rewardable in having appropriate rewards for accomplishing a set goal.

- Time deadline in having an end date.

Attention to a SMART framework can help the human brain remain present to its priorities. It will help the 'reticularactivating system' to collect, pick-up and attract all that are necessary to enable someone to achieve set goals (GarciaRill 1997:2):

- Trimming. The redirection of the way spending is adopted rather than an end to spending. The intent is to live on less than someone's earnings. Harris and Coonradt (1999) stress that 'financial security is more about how you spend than how much money you earn'.

- Training. The process of acquiring, keeping and managing money comes with ongoing financial education and training. Good financial stewardship is a commitment to growing someone's financial knowledge. The Internet, mass media, workshops and books are good sources to grow that knowledge. Successful financial management is 'the result of preparation meeting an opportunity' (Davidson, Grosso \& Gunn 2010:23). The preparation is acquired through training. Generally, 'the people who understand money spend it on assets that generate wealth; the people who don't understand money spend it on things that consume wealth' (Harris \& Coonradt 1999). Training could deepen someone's understanding of money and how to use it wisely.

A practical way to adhere to the above-mentioned principles is to have a personal budget. The latter helps allocate and manage resources responsibly, which in turn will determine the quality of someone's future. It is a good way to think through financial priorities which lead to a decision over what to spend money on.

Although the wisdom behind being debt free is indisputable, it is, however, important to note that not all debts are bad. Some of them can be a good investment in valuable assets. For example, the majority of the people can only afford to buy a house or a car through a loan. The latter are liabilities because they are loans. However, they can be good assets that provide a safe shelter for a household and a needed mode of transportation which can incentivise productivity.

\section{Generosity as the key to financial freedom}

The team was taught that generosity is critical to financial success. It is a discipline that every individual aspiring to 
financial success should practice regularly. In the ICSA local community, there is a general assumption that financial generosity can only be performed by the rich because they have more than what they need. The community, however, has experienced generosity from many of its fellow residents who share their food, space and other belongings with others. Many of these generous neighbours would be classified as poor because of the level of their income. The team was taught that Christians are called to be generous by giving more than receiving (Ac 20:35). This law points out to two mindsets: poverty and abundance.

\section{The poverty mindset}

This is also called the 'half-empty glass' mindset (Shafir 2017:132). It is when someone constantly feels that he/she does not have enough money. When someone feels financially powerless and sorry for themselves and is anxious over every cent. As a consequence, there is no openness to giving or even awareness of what might be trying to flow to them. The majority of the people in the room identified with this mindset because they saw themselves as poor and needing financial assistance from others to study or buy things they need. They could not see how possible it was to share with others the 'little' income they get.

\section{The abundance mindset}

This is also called the 'half-full glass' mindset (Radjou et al. 2015:213). It is when someone feels in control of his or her money, has a budget, has goals and feels that he or she has enough to be generous with. This person becomes open to giving and to financially partner with a certain cause for the common good.

Nobody in the room was identified with this mindset because it sounded like there were more things they needed than what their income could cover. The abundant mindset has a positive impact on the third law.

\section{Prioritising self-payment}

This is about saving a percentage of an income. A generous mindset has enough to save, give and spend. Most people in the room said that they did not have savings because they tell themselves that they will save whatever is leftover at the end of the month. Unfortunately, there was never anything left at month end. This may be a reality for many households in South Africa (Smith 2019). A way to challenge this general reality is 'to pay yourself first' (Finney 2019). As soon as an income is received, it is advised to take percentage and save it. With it out of sight, it will become out of mind and someone will live within the reduced amount. This exercise will change someone's psyche, self-esteem and attitude towards finances, especially as savings grow. Savings provide the peace of mind and the buying power every adult needs for his or her sanity. The practical recommendation from the finance broker was for people to practice spending a maximum of $70 \%$ of their income, dedicate $20 \%$ towards generous causes and save $10 \%$. This is a discipline that could prepare a consumer to wisely interact with the fourth law.

\section{Emotion the archenemy of wealth}

Many decisions consumers make about what they buy tend to be emotional and then supported by logic if required: snap decisions, retail therapy, buying stuff because of shop sales are emotional impulses that all lead to either debt or cupboards full of clutter and debt. The media and social environment tend to have a significant impact on consumers' decisions in our local community. There is a general tendency for people wanting not to appear poor in our local community. This tendency is expressed through the wearing of expensive brand names, driving expensive cars or eating red meat (the most expensive meat). The main culprit in this tendency is status seeking. It makes people pretend to be who they are not. It also makes them prone to envy and to long for things they do not have whilst overlooking things they already have. This tendency can cause much unhappiness and a spirit of jealousy.

It is important to note that emotion should not be entirely dismissed in purchasing things. Emotion can lead to good and wise decision-making. Someone can, for instance, buy clothes they like and need. The emotional energy behind such a purchase could lead someone to take good care of them. It can also be healthy for an employee to enjoy the fruit of his or her labour by treating themselves to something nice in a measured and affordable way.

\section{Nothing is free of charge}

The team learnt that in most areas of life, especially in terms of money and finances, nothing is for free. Marketing and advertising tend to portray some sale and deals as free of charge as a strategy to lure consumers into emotional decisions. Consumers can also be lured into promises of great returns from different financial schemes. Often, they end up losing their hard-earned money. As a matter of principle, whenever a financial deal is too good to be true, it is just that: too good to be true. Hence, the wisdom would be to avoid such deals. The trainer even cautioned the team about accepting charity, money or aid for free. According to him, such acceptance can have a price. It can cause emotional debt and create bondage. He advised a team such as ICSA that is $100 \%$ dependant on financial donations to seek to build partnerships that are mutually beneficial to all parties involved. This perspective was insightful and is still work in progress within the team.

\section{Reflection}

The number of trainees was 31 and all of them had a source of income. The big test here was to implement the laws and principles of financial stewardship learnt from David Finney. The bottom line was to apply the 10/20/70 rule. The latter stipulates that every income earner should learn to live on $70 \%$ of their income, be generous with $20 \%$ and save $10 \%$. 
The majority of the trainees consistently spent $100 \%$ of their income on themselves. Some spent their income with their nuclear families.

One of the outcomes of this training was that the trainees agreed to form an accountability group to encourage one another in changing their habits to implement the 10/20/70 rule. This group agreed to meet for 6 months once a month. From the onset, the group recognised that the order of numbers in the rule went from the hardest to the easiest. Spending money was something that everyone knew how to do very well. Generosity was something that many of them had practised before, especially with family members, friends and classmates. For churchgoers, which was the majority of the group, offering/tithe was a familiar concept and they saw it as a way to be generous. Saving money was an unknown or unusual habit for many of them because they felt that their 'income was below' what they needed to spend money on (Kabongo 2020:3).

After 6 months of gathering, it was discovered that the majority of the trainees had made an effort to change their habit of handling money. Out of 31 people, 25 (81\%) of them were intentional about being generous. They shared their income with family members. One of the challenges this accountability group set was for people to learn to be generous to non-family members. Of the 25 people, only seven $(28 \%)$ people were able to be generous both with family and non-family members. The rest kept it in the family. On average, the 25 members spent $8 \%$ of their income towards generosity, not the prescribed $20 \%$. This showed that this habit was still work in progress. InnerCHANGE encourages its staff to not neglect to do good and share what they have with anyone they can help (Heb 13:16). It believes that the habit of being generous, especially outside of someone's family, could prepare someone to become a good servant of 'the public and common good' (Kabongo 2020:6). Such a habit also shapes a person into a selfless being whose actions would be geared more towards pleasing God in being a blessing to others around him or her than self-promotion which is a trend in our post-modern world. Such characters are needed for the building of our local communities as well as our nation in general.

For the habit of saving, only six (19\%) people were able to do it consistently. Collectively, they saved an average of $5 \%$ of their income. After these initial 6 months, the team resolved to continue meeting for another 6 months because everyone agreed these meetings challenged them to comply to the $10 / 20 / 70$ rule and some of them were already reaping the benefit of developing the habit of being generous and saving money. Smith (2016:29) talks about the power of 'habits' for character building. At the end of this extended 6 months, all the trainees reported to practising generosity. However, only $11(35 \%)$ of them did it outside the confines of their family. On average, the group spent $11 \%$ of its income on generosity, which was still lower than what it was advised to do. In terms of saving money, nine (29\%) people were able to do so. Their overall average of savings was $6 \%$. This was still lower than what was advised. InnerCHANGE South Africa encourages people to cultivate a habit of saving money for the future. It considers this as a discipline of planning. For many of its neighbours, planning for the future seems to be a foreign concept. They live in a traumatic environment of violence, crime and pandemics such as human immunodeficiency virus (HIV)/acquired immune deficiency syndrome (AIDS) and other diseases that they see many people around them dying regularly. There seems to be a collective mindset that 'I am the next one in line to die', therefore, planning for the future could be seen as pointless. The reality, although, is that many people survive through the traumatic circumstances they live under. Additionally, our South African population is increasing. Statistics South Africa (2020) estimates of the South African population is 59.62 million in 2020. Whereas it was at 56.2 million in 2016. This shows that many people survive through the traumatic circumstances they live under. Therefore, planning for the future is wisdom. InnerCHANGE South Africa serves alongside many young adults who still aspire to pursue tertiary education, yet their parents or guardians cannot afford to fulfil their aspiration. Many of them are not approved for government-sponsored loans to allow them to study. For the working youth, saving money from their income could make their dream come true. Some young adults ICSA works with aspire to get married, for instance. Getting married involves many expenses. A habit of saving could alleviate the stress of the expenses people who get married have to incur.

Overall, this experiment of applying the 10/20/70 rule was a knowledge capital for ICSA as an organisation. It learned to monthly save a percentage of its income and was challenged to be a good steward of its generosity budget, which is $50 \%$ of its income. This experiment also taught it to take seriously the personal finances of its staff, so that they can become good stewards of what they earn. This stance aims to prepare each one of them to manage bigger things such as an organisation or a business. The Bible also teaches about being faithful in little things, so that we can be entrusted with bigger things (Mt 25:23). The outcome of this year-long accountability meetings was reported to the ICSA board of directors. The latter decided that the organisation should aim to save at least $15 \%$ of its income as a way to implement the teaching from the finance broker. It also decided to diversify fundraising efforts. Up until then, ICSA raised its funds only from Christian individuals, churches, foundations and businesses. There was also a need for InnerCHANGE to increase its income because it had started new socio-caritative initiatives which necessitated finances.

\section{Organizational finances}

This new target instructed by the board of directors came as a challenge for an organisation that was chronically underfunded. It meant that it had to start by working on the team vision, so that it can be broad without losing its identity as a mission organisation. As a global missional organisation, InnerCHANGE's vision is to 'cultivate disciples of Jesus and 
to develop local leaders who are marked by merciful action, transformative contemplation, and prophetic justice' (Statistics South Africa 2020; innerchange.org 2020). Its members pursue this vision in seeking to do justice, love mercy, and walk humbly with our God' (Mi 6:8). InnerCHANGE South Africa contextualised this vision in these words:

InnerCHANGE South Africa exists to incarnationally live and serve amongst the poor in order for our communities to be transformed and disciples of Jesus to be made. We want to follow Jesus whole-heartedly, and collaborate with Him and with our neighbours to see movements of God's Kingdom in (our context) and beyond.

This vision meant to capture our identity as a global missional organisation and our value in community development as a local team. From the casting of this vision, ICSA started investing the majority of its time doing community development efforts as a platform for its discipleship focus. This vision also led it to diversify its fundraising efforts.

\section{Fundraising}

As an organisation, ICSA writes many funding proposals yearly. Below is the outlining of a structure of a funding proposal it has found helpful. It learned about this structure from Novo (www.novo.org 2020). The structure is as follows.

\section{Executive summary}

This is a summary of the history of the organisation, its vision and mission, how it is connected to a particular societal need intended to be addressed, and the total budget of a project. It is advised that this part takes a maximum of one page and is on the first page of a proposal after the table of content. Some donors only have time to read through one page. Others look for many details. It is important to accommodate both preferences in one document.

\section{Organisation history}

History captures the track records of an organisation starting from its sense of vision, mission and purpose. Many donors make their decisions to trust a certain organisation based on the past. The financial management track record of an organisation is critical here. Many funders require a 2-year audited financial statement of an organisation. And they usually only fund organisations with unqualified statements.

\section{Project need}

This part highlights the problem statement an organisation wants to address. It may also highlight what societal issues the organisation is connected to and wants to participate in addressing.

Many of ICSA service projects are connected to the United Nations Sustainable Development Goals. It has many partners such as businesses and foundations that are committed to making these United Nations' goals a reality.
They sometimes financially partner with it to achieve these goals.

\section{Project overview}

Here it is important to explain how an organisation that intends to participate in addressing a societal problem will operationalise it. Whilst it is important to show how an organisation will participate in addressing a societal need, it is equally important to demonstrate how the funder's goals are connected to that organisation.

\section{Project outcomes}

Results matter to funders as well as to the people we serve. It is, therefore, important to write hoped for and projected results as key priorities. The latter need to be visited regularly in order to assess the effectiveness of plans or goals. It is advised to do regular debriefs as a way to assess the implementation of these priorities.

\section{Project leadership}

Funders are also interested in knowing who is leading the project to be funded, their expertise and experience in the matter. There is a saying that 'an organisation's most valuable asset is its human capital'. It is, therefore, critical to have a person or a team of people who will be an asset in the execution of the project if we hope the desired outcomes to come to pass.

\section{Project budget}

It is important to provide an itemised budget detailing the amount of money requested and how it will be spent.

\section{Project sustainability}

A funder normally does not want to be the only financial partner of a congregation or organisation. A diversity of partners is usually a fertile ground to bring in new ones. It is also strategically critical to envision a self-sustaining project and persuasively describe that.

With regard to the new financial target set by the board of directors, ICSA included non-Christian organisations in sending out funding proposals. Some rejected the proposals based on our faith. They argued that a focus of one faith usually excludes other faiths and threatens the quest of the common good. Other organisations committed to funding ICSA community development initiatives. They sent their representatives to come and see what ICSA does. Through these site visits, they were convinced to financially support ICSA. It is important to note that all of these non-Christian organisations only committed to funding projects, not salaries or administrative cost. They also required ICSA to spend every cent it was given to projects they decided to fund, and ICSA had to send an expense report for accountability. This came as a relief and a complement to the existing fundraising efforts in the Christian world ICSA focused on previously. These efforts consisted of broadening the network of individual, foundations and churches, so that 
it can raise enough money for salaries, administrative expenses and savings. InnerCHANGE South Africa has a track record with Christian donors being open to funding all of its needs: salaries, administration expenses and the cost of running our ministries. It is only through this funding stream that it could save money. It is important to note that generally ICSA only gets $10 \%$ of positive responses to fundraising efforts. Its proposals are sometimes rejected by both Christian and non-Christian organisations. It uses the five pillars to financial sustainability' advised by Appiadu (2019:43) to remain afloat. These pillars are:

1. To develop and maintain strong stakeholder relationships. The latter are financial supporters, beneficiaries of its services, staff and volunteers.

2. To prioritise fundraising, so that the organisation can obtain opportunities, especially unrestricted funds.

3. To build some savings in learning to spend less than what it raises.

4. To regularly assess and manage risks and challenges, so that it does not run out of money.

5. To wisely manage and finance overhead costs.

The implementation of these pillars is still work in process. InnerCHANGE South Africa is committed to remaining present to them with the hope to become a sustainable organisation.

\section{Reflection}

InnerCHANGE South Africa's attempt to be equipped in financial literacy came from a desire to be better servant leaders in practical ways in local communities it immerses in. Mana (2005:81) encourages the church to be involved in practical service projects as a way of contributing to the 'reconstruction' of Africa. Maluleke (2008:63) posits that 'if the church was to retain relevance' in African local communities, it has to be tangibly involved in issues that are meaningful to ordinary people. Service projects are a way ICSA tries to actively posture itself as a listener to what is meaningful to its neighbours. It believes in sustaining its projects through collaborative efforts of involving 'others' as partners (De Beer \& Van Niekerk 2017:237). InnerCHANGE South Africa works in partnership with its financial partners and neighbours to seek sustainable solutions. It is with this intent that all its service projects are run by local leaders who are some of its partners. The latter oversees the budget of the projects they head up. Hence, the importance to become financially literate. This importance is stressed in an environment that is very familiar with local churches and non-profit organisations that split regularly. The main reason for their split seems to be the management of finances and other material assets. It seems like their 'schisms' are related to the unequal share of their financial resources (Mwambazambi 2011:5-6). Many neighbours have learned to connect the split of a church to 'mismanagement of funds' (Ahiabor \& Mensah 2013:115). It seems like local churches and non-profit organisations 'are run as private and personal businesses' by their leaders, not as structures for the public and common good (Mashau \& Kgatle 2019:6). This may be one of the reasons why many of these institutions 'struggle to finance their ministries and activities' because the majority of their funds only benefit a few individual members (De Verre Naasten 2014:5). This struggle for sustainability is predictable when there is a lack of system control. In our local community, we see many people with willing hearts, yet unskilled in terms of financial management, who are in charge of the finances of local churches and non-profit organisations. Appiadu (2019:89) stresses that 'people with financial skills be given the responsibility to oversee finances'. The reality, however, is that in many African communities of poverty, it is not common to have an accountant or someone trained in areas of finances in a congregation. Many pastors and leaders have to wear many hats, one of them being that of the financial manager, to run their congregations or organisations. Learning about financial literacy from an expert such as David Finney was a treat and privilege ICSA still treasures. InnerCHANGE South Africa would advise other local churches and nonprofit organisations to get training in finances in order to improve their checks and balances which is a tried and test pathway to organisational sustainability. It is said that 'great leaders are made, not born' (Tsuma, Siringi \& Wambua 2019:30). Similarly, good financial managers are made, not born. It is, therefore, critical for ministers, faith-based organisation leaders and other local non-profit organisation leaders to undergo financial management training in order for them to well manage their organisations.

For ICSA, this training in financial literacy opened another door which helped improve its fundraising outcomes. Up until this training was completed, fundraising efforts were the responsibility of staff members only. When its board of directors set the target of saving $15 \%$ of the organisation income per annum, it also challenged itself to be involved in fundraising. The board efforts helped to raise $20 \%$ of the team funds during the 2018-2019 financial year (ICSA annual general meeting minutes, April 2019). During the 2019-2020 financial year, it raised 23\% (ICSA annual general meeting minutes, August 2020). These funds came entirely from nonChristian organisations. The board of directors also adjusted its decision of saving $15 \%$ of the team funds from a projected budget to this income. This adjustment came when the team was unable to save any money because it was underfunded from its projected budget. The underfunding is a reality to this day. However, the team was able to save $11 \%$ of its income in 2019 and has saved so far 16\% of its 2020 income. The increase in savings is connected to increased income, thanks to the collaboration between the board and staff in fundraising efforts.

InnerCHANGE South Africa would like to continue growing in this fundraising efforts because it would like to sustain its current practical ministries and future ones. These ministries are the primary platforms it uses to disciple many of its neighbours. Discipleship is, in fact, its central ministry focus. Because tangible services to a community is 'the song' 
it sings, discipleship and the development of human capacity are about how it adds more singers to the choir (Metcalf \& Prince 2018:2). Finances are needed to sustain these platforms and respond to other financial needs such as the current coronavirus disease 2019 pandemic realities. With this pandemic, many ICSA neighbours needed relief in the form of food parcels soon after the government of South Africa shut down all non-essential activities on 17 March 2020. InnerCHANGE responded to this emergency and bought and distributed food parcels to some needy neighbours. The team used its savings to respond to this emergency. It then did some fundraising to continue this relief effort. Few months after the lockdown restrictions were eased by the South African government, InnerCHANGE resumed some of its services. Such a decision had financial implications because non-budgeted things such as hygienic and healthcare products had to be purchased. Financial affordability was an important part of the decisions to resume some of the service projects. The team also used its savings to comply with the new measures of curbing the spread of this pandemic.

\section{Conclusion}

This article was a case study reflecting on the efforts of ICSA to become a financially sustainable organisation. InnerCHANGE South Africa used the expertise of a finance broker to get some training in financial literacy. The aim of these efforts was for organisational benefits. The finance broker taught that the best way leading to that aim was to start with personal finances. This training led the board of directors to set the target of saving $15 \%$ of the organisation income yearly. It also led the directors to be involved in fundraising, whereas before, fundraising was performed only by staff members. These efforts helped improve the organisation finances although it is still work in progress.

\section{Acknowledgements}

The author would like to thank David Finney for training InnerCHANGE staff and associates in personal finances.

\section{Competing interests}

The author has declared that no competing exists.

\section{Author's contribution}

I declare that I am the sole author of this research article.

\section{Ethical considerations}

This article followed all ethical standards for a research without direct contact with human or animal subjects.

\section{Funding information}

This research received no specific grant from any funding agency in the public, commercial or not-for-profit sectors.

\section{Data availability}

Data sharing is not applicable to this article as no new data were created or analysed in this study.

\section{Disclaimer}

The views and opinions expressed in this article are those of the author and do not necessarily reflect the official policy or position of any affiliated agency of the author.

\section{References}

Ahiabor, G. \& Mensah, C.C.Y., 2013, 'Effectiveness of internal control on the finances of churches in Greater Accra, Ghana', Research Journal of Finance and Accounting $4(13), 115-120$.

Appiadu, E.T., 2019, 'Evaluating the financial management practices in the sustainability of Pentecostal-Charismatic churches', unpublished master's degree dissertation, North West University, Mahikeng.

Clason, G.S., 2018, The richest man in Babylon, Samaira Books, Ghaziabad.

Davidson, S.M., Grosso, D.S. \& Gunn, T.A., 2010, 'Preparation meets opportunity: An entrepreneurial journey', International Journal of Entrepreneurship 14, 23.

De Beer, S.F. \& Van Niekerk, A.S., 2017, 'Transforming curricula into the next century: Doing theology collaboratively with local communities', Verbum et Ecclesia 38(4), a1683. https://doi.org/10.4102/ve.v38i4.1683

De Verre Naasten, 2014, De Verre Naasten strategy paper supporting churches to become financially sustainable, viewed 12 June 2020 , from https://verrenaasten.nl/.

Finney, D., 2019, 'Workshop on personal finances', unpublished notes, Soshanguve.

Franklin, B., 2007, The autobiography of Benjamin Franklin: 1706-1757, vol. 1, Regnery Publishing, Washington, DC.

Garcia-Rill, E., 1997, 'Disorders of the reticular activating system', Medical Hypotheses 49(5), 379-387. https://doi.org/10.1016/S0306-9877(97)90083-9

Harris, B. \& Coonradt, C.A., 1999, The four laws of debt-free prosperity, Lee Nelson, Spring, Springville, UT.

InnerCHANGE, 2020, About, viewed 02 July 2020, from www.innerchange.org/.

InnerCHANGE South Africa, 2019, 'Annual meeting minutes, April 2019', Unpublished notes, Soshanguve.

InnerCHANGE South Africa, 2020, 'Annual meeting minutes, August 2020', Unpublished notes, Soshanguve

Kabongo, K.T.L., 2020, 'A partnership for prosperity agency: A case study of InnerCHANGE South Africa', Theologia Viatorum 44(1), a48. https://doi. org/10.4102/TV.v44i1.48

Latvus, K., 2010, 'Diaconal ministry in the light of the reception and re-interpretation of Acts 6: Did John Calvin create the social-caritative ministry of diaconia?', Diaconia 1(1), 82-102. https://doi.org/10.13109/diac.2010.1.1.82

Maluleke, T.S., 2008, 'May the black God stand please: Biko's challenge to religion', in A. Mngxitama, A. Alexander \& N.C. Gibson (eds.), Biko Lives!, pp. 115-126, Palgrave Macmillan, New York, NY.

Mana, K., 2005, La mission de l'Eglise Africaine, Cipro, Yaounde.

Mashau, T.D. \& Kgatle, M.S., 2019, 'Prosperity gospel and the culture of greed in postcolonial Africa: Constructing an alternative African Christian theology of Ubuntu', Verbum et Ecclesia 40(1), a1901. https://doi.org/10.4102/ve.v40i1.1901

Metcalf, S.F. \& Prince, D., 2018, People first: The human redemptive priority, Novo Foundations, Anaheim, CA.

Meyer, P.J., 2003, Unlocking your legacy: 25 keys for success, Moody Publishers, Chicago, IL.

Mwambazambi, K., 2011, 'A missiological refection on African ecclesiology', Verbum et Ecclesia 32(1), Art. \#482, 8 pages. https://doi.org/10.4102/ve.v32i1.482

Novo, 2020, Funding proposal outline, viewed 20 January 2020, from www.novo.org.

Odiorne, G.S., 1990, The human side of management, Lexington Books, Washington, DC.

Radjou, N., Prabhu, J., Ahuja, S. \& Roberts, N., 2015, Frugal innovation: How to do better with less, Public Affairs, New York, NY.

Shafir, E., 2017, 'Decisions in poverty contexts', Current Opinion in Psychology 18, 131-136. https://doi.org/10.1016/j.copsyc.2017.08.026

Smith, C., 2019, Household savings rate in SA actually zero-economist, viewed 09 February 2020, from www.fin24.com.

Smith, J.K.A. 2016, You are what you love. The spiritual power of habit, Green press initiative, Grand Rapids.

Statisitics South Africa, 2020, 2020 Mid-year population estimates, viewed 01 September 2020, from http://www.statssa.gov.za/.

Tsuma, D.M., Siringi, E. \& Wambua, L., 2019, 'The intervening effect of leadership style in the relationship between stakeholder engagement and sustainability of Anglican Church funded projects in Kenya', Journal of Human Resource \& Leadership 3(3), 27-43. 